\title{
The Effects of Materialism and Consumer Ethics on Ecological Behavior: An Empirical Study
}

\author{
Hülya Bakırtaşa, G. Canberk Buluşa İbrahim Bakırtaşa
}

\begin{abstract}
World populations have increased day by day. Thus, production volume of companies have increased depend on increasing population. Besides, fashion and/or technology influence consumer's goods or services purchasing decision. Consequently, the type and the number of product produced have increased and natural resources both more are being used and depleted. At this point has come to the fore the consumer's environmental concern and ecological behavior and has gained importance. Studies about environmental concern in marketing began depending on living of some problems in the early 1970s. Environmental concern concept assesses in terms of both individual concern and social concern. Individual concern states to abuse of the environment of individual consumers while social concern states perceived need for social, political, and legal changes to protect the environment. There is a positive relationship between environmental concern and ecological behavior. This study was examined the relationship between materialism, consumer ethics, environmental concern and ecological consumer behavior.

This study was carried out between dates of September and November 2013. To test the hypotheses of the study, regression analysis has been used. Results show that consumer ethics has positive impact on both environmental concern and ecological behaviour of consumer. Besides, materialism has negative impact on ecological behaviour.
\end{abstract}

Keywords: Environmental concern, consumer ethics, materialism, ecological behavior.

\section{Introduction}

As humans come into being in the environment, and they live and develop with it, their environmental concern starts with their existence. Also, next generations of humans are entrusted to the environment. Due to their respect for environment and belief that they need environment to maintain their own life, humans had generally lived in harmony with the environment until the Industrial Revolution in the 1750s. However, the Industrial Revolution intensified materialism, which was already present in the human nature. The motivation to have more and the belief that more consumption brings more pleasure have placed the material in the center of human life (Fourner and Rishins, 1991). Essentially, the feeling of acquiring material goods is a natural and healthy part of human nature. Whereas, when a specific threshold is exceeded, materialism starts damaging both individuals and the society (Muncy and Eastman, 1998). Great competition caused by the Industrial Revolution not only increased colonialism and despoliation but also led to the World War II. In the years following the Second World 
War, especially as ofthe 1960s, studies related to social sciences including psychology, economics, etc. aimed to understand the environment as well as human beings. In other words, environmental concern attracted researchers' attention (Stisser, 1994; Kilbourne and Pickett, 2008; Eckhardt et al, 2010).

Many scientists consider the "Earth Day" 1970 as the first modern environmental movement. Although the 1970s are known as the "Environmental Decade", energy problems in mid-1970s and related decline in the welfare of Western society decreased the public support for environmental issues (Krause, 1993). On the other side, the political climate and government policies created under the leadership of Reagan and Bush raised an "adverse response" in the public and increased environmental concern and commitment (Dunlap and Scarce, 1991). Environmental concern became a dominant social theme in the 1990s. As researchers and environmental organizations underline the importance of the problems facing our planet, environmental concern of people increases day by day (Ottman, 1993; Stisser, 1994; Thapa, 2001).

The fluctuating trend of the environmental concern in the history brings the following question to mind: Do human beings behave more materialistic and less ethical when they have concerns about their welfare? Shafik (1994) reports that the functions reflecting relative costs and benefits of individuals and countries related to environmental issues vary at different stages of economic welfare. Both Feather (1998) and Ger and Belk (1996) indicate that materialist values tend to increase in developing countries. Compared to middle income and poorer countries, developed economies, which are in the search of more clear air and relatively clean water resources, and emerging markets still facing serious environmental problems have relatively higher environmental standards and more stringent environmental legislations (Grossman and Kruger (1995). The Environmental Kuznets Curve (EKC) analyzing the relationship between income and environmental degradation summarizes all these information mentioned above (Stern, 2004).

Considering historical process of environmental concern and the information in the EKC are, we can reach the following conclusions: First, materialism, if exceeds the limits, is the reason for many environmental problems (Bredeme and Toby, 1960) and similarly the solution of many problems lies in consumer ethics (Fisk, 1973). Second, consumer ethics become more virtuous and materialism withdraws to its natural boundaries in case of welfare (Inglehart, 1981; Hirsh and Dolder, Finance, 2007; Eckhardt et al., 2010). These two arguments have provided guidance while deciding the research question. In this context, this study aims to analyze how materialism and consumer ethics, directly or through environmental concern, affect the ecological behaviors of consumers. The present study contributes to the literature by addressing materialism and consumer ethics within the same structural model regarding them as the determinant of environmental concern.

\section{Conceptual Framework and Research Hypotheses}

Materialism can be defined with different words. However, all definitions shall involve the term "secular/earthly goods". If we base our definition on that common term, materialism is the set of values related to secular goods (Belk, 1985; Richinsand 
Dawson, 1992; Browne andKaldenberg, 1997). Materialism attaches importance to acquiring material rather than the benefits of the material that have been acquired (Kilbourneand Pickett, 2008). Belk (1985) scaled materialism in three dimensions; jealousy (bad faith against another's success), the desire to have (the tendency to have control of one's own belongings) and parsimony (unwillingness to share) while Richins and Dawson (1992) analyzed materialism under other three headings, namely success (defined as the success of having), centralization (center of buying) and happiness (buying as the pursuit of happiness).

Consumer ethics is a set of ethical principles and standards guiding individual and group behaviors in the course of meeting liabilities on the use of goods and services, and disposal of residues with a consumption perspective based on environmental consciousness. Vitelland Muncy (1992) indicate that consumer ethics has 4 dimensions. These dimensions are: Actively benefitting from illegal activity (for instance changing the price-tags on merchandise in a store), passively benefitting at expense of others ( for instance, not saying anything when the cashier pays more change than she should), actively benefitting from questionable action (for example, breaking an object in the store and pretending as if you did nothing), and passively benefiting a harmless-looking activity (for example, copying movie or software from TV or computer).

There are various views regarding the relationship between materialism and consumer rights. One view suggests that materialism can be questioned with a moral perspective (RudminandRichins, 1992). Another one states that high level materialism is related to immoral behaviors (Barrett, 1992) and a third one claims that high level materialism brings inevitable losses to the society, people become more insensitive towards environment and that situation shall affect individuals in a negative way (Belk, 1988). Muncyand Eastman (1998) state that materialist consumers believe that they need to be wealthy to be happy, and thus, feel greater pressure compared to less materialistic consumers. Therefore, materialist consumers are more likely to behave unethically in order to have the thing they desire (Muncy and Eastman, 1998). As materialism and consumption are closely related, there is also a relationship between materialism and consumer ethics. However, there is uncertainty on whether the relationship between these variables is causal or non-casual (Muncyand Eastman, 1998). Despite this uncertainty, when the other aforementioned information is taken into consideration, both variables are expected to have influence on environmental concern.

As well as being an important topic on the agenda of Western developed countries, environmental issues awoke environmental concern in public in the 1970s (Dunlop et al., 2000, Crane, 2000). Environmental concern of people show an increase when they recognize that environment, the source of existence, is under threat. Although Kilbourne and Pickett (2008) claim that environmental concern cannot exist without environmental beliefs, environmental concern, in fact, contains environmental beliefs in itself. People with low environmental concern also have low environmental beliefs. Therefore, materialism, consumer ethics and moral/immoral consumer behaviors are directly related to environmental concern rather than environmental beliefs.

First marketing studies on environmental concern go back to 1970s. At that time, researchers including Anderson and Cunningham (1972), Kinnear et al. (1974) and Dunlop and Van Liere (1978) analyzed environmental concern in consumers and 
developed some scales. Among these, the scale developed by Dunlop and Van Lier (1978) is the one based on the most comprehensive environmental concern definition. Afterwards, Dunlop et al. (2002) redefined environmental concern in 5 different dimensions in their New Environmental Paradigm (NEP) Scale. These dimensions are reality of limits to growth, the fragility of nature's balance, antianthropocentrism, rejection of exermtionalism and the possibility of an ecocrises. If consumer has a strong belief in that the more s/he has the more s/he becomes happy, her/his environmental concern is low (Kilbourne and Pickett, 2008). On the other hand, if the level of consumer ethics increases, environmental concern will also increase. Because people respect the environment and know that they need it for the continuity of life.

Based on the predominant view in the literature, these are hypothesized that:

$\mathrm{H}_{1}$ : Consumer's environmental concern is negatively affected by materialism.

$\mathrm{H}_{2}$ : Consumer's environmental concern is positively affected by consumer ethics.

As people become aware of various environmental issues, increased environmental concern affect their behaviors in many areas from the types of goods they consume to the political parties they vote for (Minton and Rose, 1997). Researchers have sunk themselves into the effort of developing various scales for defining environmental behaviors as well as environmental concern. Maloney et al. (1975), and Dietze et al. (1998) are two good examples of those researchers. The major problem encountered in the process of environmental behavior identification is the necessity to combine very different and independent variables into the same identification. Dietz et al. (1998) conceptualized ecological behavior in their environmentally responsible behavior (ERB) scale consisting of 3 dimensions (namely consumer behavior, environmental citizenship and policy support).Maloney et al. (1975)developed a scale identifying environmental behavior in four sub-scales. These four sub-scales are: verbal commitment, actual commitment, affect and knowledge. Actual commitment is also called ecological behavior (Frajer and Martinez, 2007). Therefore, it is hypothesized that:

$\mathrm{H}_{3}$ : Environmental concern of individuals will positively influence their ecological behavior.

As stated in the introduction of the study, materialism and consumer ethics are expected to affect consumer's ecological behavior. In line with these expectations, the following hypotheses have been developed:

$\mathrm{H}_{4}$ : Materialistic values of individuals will negatively affect their ecological behaviour.

$\mathrm{H}_{5}$ : Consumer ethics of individuals will positively affect their ecological behaviour.

The conceptual model which integrates the hypothesized relationship (Hypotheses 1, 2, 3, 4 and 5) appears Figure 1. The relationships among the four constructs depicted in this model were empirically tested based on consumer data collected in Turkey. 


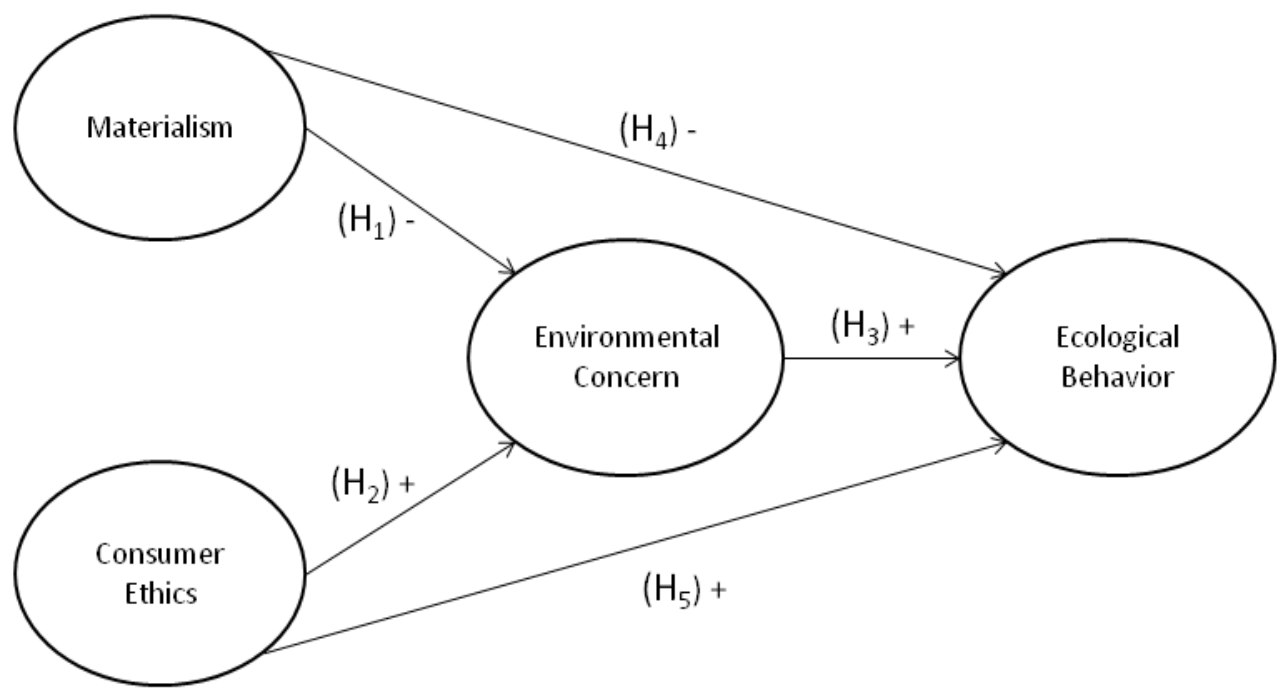

Figure 1. Proposed Causal Model

\section{Methodology}

This study was carried out between dates of September and November 2013. The data of the study have been collected by questionnaire methods. To test the hypothesis, a sample of 415 adult Turkish was completed a questionnaire including material values scale with eighteen items adapted from Richins and Dawson (1992) for materialism, consumer ethics scale with twenty six items adapted from Vitell and Muncy (1992) for consumer ethics, NEP scale with fifteen items adapted from Dunlop et. al. (2000) for environmental concern, GREB scale with ten items adapted from Cottrell, (2003) for ecological consumer behavior. But, all analyzes were made according to 302 usable data.Demographic features of participants are given in Table 1.

\subsection{Analysis and Results}

Firstly, of all scales used in the study was investigated to reliability (Cronbach Alpha). Only,Cronbach Alpha value of consumer ethics scale with four factorwere greater than 0.60. Thus, for other scales (EC, MAT and EB) was made to exploratory factor analysis for determine structural validity of scale.

The factor analysis of environmental concern construct is shown in Table 2. As a result of factor analysis, as regards environmental concern were obtained one factor solution with Eigen value $>1$. One factor solution obtained explains approximately $47 \%$ of the total variance. The principal components and varimax rotation methods were used. Based on the results of Kaiser-Meyer-Olkin (KMO) measure (0.750) of sampling adequacy and Barlett'ssphericity, the variables and data in the study were found to be appropriate for exploratory factor analysis. Besides, Cronbach Alpha was 0.712, thus were supported internal consistency of the scales. 
Table1. SampleCharacteristics

\begin{tabular}{|c|c|c|c|}
\hline SampleCharacteristic & CategoricalScale & $\mathbf{N}$ & $\%$ \\
\hline \multirow{2}{*}{ Gender } & Female & 177 & 59 \\
\hline & Male & 125 & 41 \\
\hline \multirow{5}{*}{ Age } & $25 /-$ & 229 & 76 \\
\hline & $26-35$ & 51 & 17 \\
\hline & $36-45$ & 15 & 5 \\
\hline & $46-55$ & 4 & 1 \\
\hline & $56 /+$ & 3 & 1 \\
\hline \multirow{4}{*}{ Education } & Primaryandsecondary & 6 & 2 \\
\hline & High school & 45 & 15 \\
\hline & Undergraduate & 234 & 77 \\
\hline & Graduate & 17 & 6 \\
\hline \multirow{6}{*}{ Income } & 749 TL andunder & 23 & 8 \\
\hline & $750-1000 \mathrm{TL}$ & 55 & 18 \\
\hline & $1001-2000 \mathrm{TL}$ & 113 & 37 \\
\hline & $2001-4000 \mathrm{TL}$ & 71 & 24 \\
\hline & $4001-6000 \mathrm{TL}$ & 31 & 10 \\
\hline & 6001 TL andover & 9 & 3 \\
\hline
\end{tabular}

Table 2. Exploratory Factor Analysis Results of Environmental Concern Construct

\begin{tabular}{|c|c|c|c|}
\hline Factor & Factor Loadings & $\begin{array}{l}\text { Variance } \\
(\%)\end{array}$ & $\alpha$ \\
\hline \multicolumn{4}{|l|}{ 1. Factor (EC) } \\
\hline C12 & 0.775 & \multirow{5}{*}{46.726} & \multirow{5}{*}{0.712} \\
\hline $\mathrm{C} 8$ & 0.691 & & \\
\hline $\mathrm{C} 2$ & 0.674 & & \\
\hline C14 & 0.642 & & \\
\hline $\mathrm{C} 10$ & 0.626 & & \\
\hline Total Variance Explained & \multicolumn{3}{|l|}{46.726} \\
\hline Kaiser-Meyer-Olkin Measure of Sampling Adequacy & \multicolumn{3}{|l|}{0.750} \\
\hline $\begin{array}{l}\text { Barlett's Test Approx Chi-Squareof Sphericity } \\
\text { df } \\
\text { Sig. }\end{array}$ & \multicolumn{3}{|l|}{$\begin{array}{l}258.594 \\
10 \\
0.000\end{array}$} \\
\hline
\end{tabular}

The factor analysis of ecological behaviour construct is shown in Table 3. As a result of factor analysis, as regards environmental concern were obtained two factor solutions. Two factor solution obtained (EB1- five variables, explained variance 36.4; EB2-two variables, explained variance 22.7) explains approximately 59\% of the total variance. Based on the results of Kaiser-Meyer-Olkin (KMO) measure (0.712) of sampling adequacy and Barlett'ssphericity, the variables and data in the study were found to be appropriate for exploratory factor analysis. Besides, Cronbach Alpha $(\alpha)$ of all the scales were greater than 0.60 . 
Table 3. Exploratory Factor Analysis Resultof Ecological Behavior Construct

\begin{tabular}{|c|c|c|c|}
\hline Factors & Factor Loadings & $\begin{array}{l}\text { Variance } \\
(\%)\end{array}$ & $\alpha$ \\
\hline \multicolumn{4}{|l|}{ 1. Factor (EB1) } \\
\hline E6 & 0.783 & \multirow{5}{*}{36.372} & \multirow{5}{*}{0.75} \\
\hline E4 & 0.759 & & \\
\hline E7 & 0.715 & & \\
\hline E5 & 0.711 & & \\
\hline E3 & 0.566 & & \\
\hline \multicolumn{4}{|l|}{ 2. Factor (EB2) } \\
\hline E9 & 0.874 & \multirow{2}{*}{22.747} & \multirow{2}{*}{0.71} \\
\hline E8 & 0.868 & & \\
\hline Total Variance Explained & \multicolumn{3}{|l|}{59.118} \\
\hline Kaiser-Meyer-Olkin Measure of Sampling Adequacy & \multicolumn{3}{|l|}{0.712} \\
\hline $\begin{array}{l}\text { Barlett's Test Approx Chi-Squareof Sphericity } \\
\text { df } \\
\text { Sig. }\end{array}$ & \multicolumn{3}{|l|}{$\begin{array}{l}465.791 \\
21 \\
0.000\end{array}$} \\
\hline
\end{tabular}

Table 4. Exploratory Factor Analysis Results of Materialism Construct

\begin{tabular}{|c|c|c|c|}
\hline Factors & Factor Loadings & $\begin{array}{l}\text { Variance } \\
(\%)\end{array}$ & $\alpha$ \\
\hline \multicolumn{4}{|l|}{ 1. Factor (MAT1) } \\
\hline M2 & 0.740 & \multirow{4}{*}{19.820} & \multirow{4}{*}{0.63} \\
\hline M4 & 0.680 & & \\
\hline M5 & 0.636 & & \\
\hline M1 & 0.545 & & \\
\hline \multicolumn{4}{|l|}{ 2. Factor (MAT2) } \\
\hline M8 & 0.695 & \multirow{5}{*}{16.794} & \multirow{5}{*}{0.63} \\
\hline M6 & 0.656 & & \\
\hline M7 & 0.622 & & \\
\hline M13 & 0.591 & & \\
\hline M9 & 0.559 & & \\
\hline \multicolumn{4}{|l|}{ 3. Factor (MAT3) } \\
\hline M15 & 0.763 & \multirow{2}{*}{13.528} & \multirow{2}{*}{0.81} \\
\hline M16 & 0.684 & & \\
\hline Total Variance Explained & \multicolumn{3}{|l|}{50.141} \\
\hline Kaiser-Meyer-Olkin Measure of Sampling Adequacy & \multicolumn{3}{|l|}{0.758} \\
\hline $\begin{array}{l}\text { Barlett's TestApprox Chi-Squareof Sphericity } \\
\text { df } \\
\text { Sig. }\end{array}$ & \multicolumn{3}{|l|}{$\begin{array}{l}473.523 \\
55 \\
0.000\end{array}$} \\
\hline
\end{tabular}

The factor analysis of materialism construct is shown in Table 4. As a result of factor analysis, as regards materialism were obtained three factor solutions. The factor solution obtained (MAT1 - four variables, explained variance 19.8; MAT2-five variables, explained variance 16.8; MAT3-two variables, explained variance 13.5) explains approximately 50\% of the total variance. Based on the results of Kaiser-Meyer-Olkin (KMO) measure (0.758) of sampling adequacy and Barlett'ssphericity, the variables and data in the study 
were found to be appropriate for exploratory factor analysis. Besides, Cronbach Alpha $(\alpha)$ of all the scales were greater than 0.60 .

To test the hypotheses of the study, five regression model were conducted. Analysis results have shown Table 5.Results show that materialism has positive impact on environmental concern contrary to expectations. Besides, the impact was not statistically significant. Thus, $\mathrm{H}_{1}$ was rejected.Model 2 was investigated impact on environmental concern (EC) of consumer ethics (ETHC). $\mathrm{H}_{2}$ hypothesis was supported when Model 2 was examined. Namely, consumer ethics influence environmental concern. Model 3 was researched impact on environmental behaviour of environmental concern. Given that analysis result of Model 3, environmental concerndo not have any impact on environmental behavior. Thus, $\mathrm{H}_{3}$ hypothesis was rejected. Similarly, Model 4 was investigated impact on environmental behaviour of materialism. Relationship between materialism and environmental behaviour was negative and the relationship was statistically significant. Last model was researched impact on environmental behaviour of consumer ethics. Results showed that consumer ethics have impact on environmental behaviour. Thus, $\mathrm{H}_{5}$ was supported. In addition to, materialism and consumer ethics has explained respectively $63 \%$ and $26 \%$ of environmental behaviour while consumer ethics has explained $3 \%$ of variance in environmental concern.

Table 5.Regression Analysis Results

\begin{tabular}{|c|c|c|c|c|c|}
\hline & Model 1 & Model 2 & Model 3 & Model 4 & Model 5 \\
\hline Var. & \multicolumn{2}{|l|}{$E C$} & \multicolumn{3}{|l|}{$E B$} \\
\hline$E C$ & & & $\begin{array}{l}0.039 \\
(0.684)\end{array}$ & & \\
\hline$M A T$ & $\begin{array}{l}0.091 \\
(1.591) \\
\end{array}$ & & & $\begin{array}{l}-0.793^{*} \\
(-22.510)\end{array}$ & \\
\hline ETCH & & $\begin{array}{l}0.193^{*} \\
(3.406)\end{array}$ & & & $\begin{array}{l}0,514^{*} \\
(10.372)\end{array}$ \\
\hline$F_{\text {ist }}$ & 2.532 & $2.532^{*}$ & 0.468 & $506.684^{*}$ & $107.577^{*}$ \\
\hline$R^{2}$ & 0.008 & 0.037 & 0.002 & 0.628 & 0.514 \\
\hline Adj. $R^{2}$ & 0.005 & 0.034 & 0.001 & 0.627 & 0.264 \\
\hline
\end{tabular}

Note: ${ }^{*} p<0.05$

\section{Discussion}

Materialism was examined by many researchers. The researchers expressed that materialism consequences have negative effectson both individual and social. Materialistic consumption would decrease ecological behaviour. Hence, this topic is becoming important for sustainability and nature environment. At this point, both public and private sector have important duties. Private sector can change perceptions regarding consumer's product choices with commercial messages. Similarly, public sector can affect consumer's environmentally products choices by non-commercial ads and can draw attention to the importance of nature environment. Besides, governments should make environmental policies for business environment. Although greater materialism for 
some countries (e.g. China) can mean greater economic growth, this can cause greater societal problems. Because materialistic behaviours can lead non-ethical behaviours. So, sustainable future depend on mobilizing of consumers, societies, firms, governments, et al.

As a result of testing hypothesis, we have found that consumer ethics influence positively both environmental concern and ecological behavior of consumer.In addition to, materialism influence negatively ecological behavior (Hurst et al, 2013). However, materialism does not influence environmental concern. Besides, environmental concern does not influence ecological behavior of consumer.Relationship between environmental concern and ecological behavior is positive, but the relationship is not statistically significant. Similarly, relationship between materialism and ecological behavior is not statistically significant, but the relationship is negative. Given that the results in terms of relationship direction is not consistent with literature (Kilbourne\& Picket, 2008; Minton \&Rose, 1997; Mainieri et al., 1997).

When the studies about ecological behavior are examined, there are many studies made to assess ecological behavior of consumers. Although these studies help to understand ecological behavior of consumers, these studies examine to the issue as either consumer ethics or environmental concern. But, this study has approached the issue with holistic perspective adding materialism. Namely, this study different from others, examines consumer ethics, environmental concern and ecological behavior all together in addition to materialism. This study is limited in some ways. First, the study carried out several city in Turkey. Second, data have been collected by questionnaire. Third, the majority of participants consist of under the age of 25.

\section{References}

Anderson TW, Cunningham WH. 1972. The Social Conscious Consumer. Journal of Marketing 36(3):23-31.

Barrett A. 1992. Crime Waves Spread Very Democratically in Czechoslovakia: Even Toilet Paper is Locked Away as New Breed of Thief Hails Western Materialism. The Wall Street Journal November 6: B7B.

Belk RW. 1985. Materialism: Trait Aspects of Living in the Material World. Journal of Consumer Researcb 12(3): 265-280.

Belk RW. 1988. Third World Consumer Culture. In Kumku E., Firat A. F. (eds) Marketing and Development: Towards Broader Dimensions, pp. 103-127. Greenwich, CT: JAI Press.

Bredemeier HC, Tobby J. 1960. Social Problems in America: Costs and Casualties in an Acquisitive Society. Newyork, NY: Wiley.

Crane A. 2000. Marketing and the Natural Environment: What Role for Morality. Journal of Macromarketing20(2): 144-154.

Dietz T, Stern PC, Guagnano GA. 1998. Social Structural and Social Psychological Bases of Environmental Concern. Environment and Behavior30(4): 450-471.

Dunlop RE, Scarce R. 1991.The Polls-Poll Trends: Environmental Problems and Protection. Public Opinion Quarterly 55(4): 651-672.

Dunlop RE, Van Liere KD. 1978. The "New Environmental Paradigm": A Proposed Instrument and Preliminary Results. Journal of Environmental Education 9(1): 10-19.

Dunlop RE, Van Liere KD, Mertig AG, Jones RE. 2000. Measuring Endorsement of the New Ecological Paradigm: A Revised NEP Scale. Journal of Social Issues56(3): 425-442.

Eckhardt GM, Belk R, Devinney TM. 2010. Why Don't Consumers Consume Ethically. Journal of Consumer Behaviour9(6): 426-436.

Fournier S, Richins ML. 1991. Some Theoretical and Popular Notions Concerning Materialism. Journal of Social Behavior and Personalitj6(6): 403-413. 
Feather NT. 1998. Attitudes toward High Achievers, Self-Esteem, and Value Priorities for Australian, American, and Canadian Students. Journal of Cross-Cultural Psychology 29(6): 749-759.

Fisk G. 1973. Criteria for a Theory of Responsible Consumption. Journal of Marketing 37(1): 24-31.

Fraj E, Martinez E. 2006. Influence of Personality on Ecological Consumer Behaviour. Journal of Consumer Behaviour. 5(3):167-181.

Fraj E, Martinez E. 2007. Ecological Consumer Behaviour: An Empirical Analysis. International Journal of Consumer Studies31(1): 26-33.

Ger G, Belk RW. 1996. Cross-cultural Difference in Materialism. Journal of Economic Psychology17(1):55-77.

Grossman GM, Krueger AB. 1995. Economic Growth and the Environment. The Quarterly Journal of Economics 110(2): 353-377.

Hirsh JB, Dolderman D. 2007. Personality Predictors of Consumerism and Environmentalism: A Preliminary Study. Personality and Individual Differences 43(6): 1583-1593.

Hurst, M, Dittmar H, Bond R, Kasser T. 2013. The Relationship between Materialistic Values and Environmental Attitudes and Behaviors: A Meta-Analysis. Journal of Environmental Psychology 36: 257-269.

Inglehart R. 1981. Post Materialism in an Environment of Insecurity. American Political Science Review75(4): 880-900.

Kilbourne W, Pickett, G. 2008. How Materialism Affects Environmental Beliefs, Concern, and Environmentally Responsible Behavior. Journal of Business Research 61(9): 885-893.

Kinnear TC, Taylor JR, Ahmed SA. 1974. Ecologically Concerned Consumers: Who are they. Journal of Marketing38(2): 20-24.

Krause D. 1993. Environmental Consciousness: An Empirical Study. Environment and Behavior25(1): 126-142.

Mainieri T, Barnett EG, Valdero TR, Unipan JB, Oskamp S. 1997. Green Buying: The Influence of Environmental Concern on Consumer Behavior. The Journal of Social Psychology 137(2): 189-204.

Maloney MP, Ward MP, Braucht GN. 1975. Psychology in Action: a Revised Scale for the Measurement of Ecological Attitudes and Knowledge. American Psychologist 40(1): 787-790.

Minton AP, Rose RL. 1997. The Effects of Environmental Concern on Environmentally Friendly Consumer Behavior: An Exploratory Study. Journal of Business Research 40(1): 37-48.

Muncy JA, Eastman JK. 1998. Materialism and Consumer Ethics: An Exploratory Study. Journal of Business Ethics 17(2): 137-145.

Ottman JA. 1993. Green Marketing: Challenges and Opportunities for the New Marketing. Chicago: McGraw-Hill.

Richins ML, Dawson S. 1992. A Consumer Values Orientation of Materialism and its Measurement: Scale Development and Validation. Journal of Consumer Research 19(3): 303-316.

Roberts JA, Bacon DR. 1997. Exploring the Subtle Relationships between Environmental Concern and Ecologically Conscious Consumer Behavior. Journal of Business Research40(1): 79-89.

RudminFW.,Richins ML. 1992. Meaning, Measure, and Morality of Materialism. Provo, UT: Association for Consumer Research.

Shafik N. 1994. Economic Development and Environmental Quality: An Econometric Analysis. Oxford Economic Paper46(Special Issue on Environmental Economics):757-773.

Stern DI. 2004. The Rise and Fall of the Environmental Kuznets Curve. World Development32(8): 1419-1439.

Stisser P. 1994. A Deeper Shade of Green. American Demographics16(3): 24-29.

Thapa B. 2001. Environmental Concern: A Comparative Analysis between Students in Reaction and Park Management and other Departments. Environmental Education Research 7(1): 39-53.

Vitell SJ, Muncy J. 1992. Consumer Ethics: An Empirical Investigation of Factors Influencing Ethical Judgments of the Final Consumer. Journal of Business Ethics 11(8): 585-597. 